\title{
READERS
Insight
}

Journal of Management Info (JMI)

ISSN:2313-3376

www.readersinsight.net/jmi

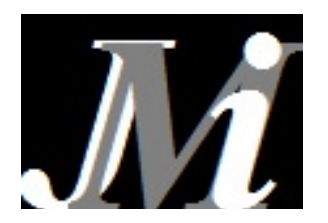

\section{Central Asian republics' relations with its neighbors and the US}

\author{
Jahanzeb Khalil ${ }^{1}$, Waseem khan², Taimoor khan ${ }^{3}$ \\ ${ }^{1}$ Department of Political Science, Abdul Wali Khan University Mardan \\ ${ }^{2}$ University of Swabi, Anbar Pakistan \\ ${ }^{3}$ Lahore University of Management Science, Pakistan \\ * Corresponding author:
}

\begin{abstract}
The Classical Great Game of the $19^{\text {th }}$ century in the region was a contest between the Russian and British empires over Afghanistan due to its geostrategic importance. The "New Great Game", being played out in Central Asia, is one in which powers on the borders of the Central Asian states, as well as the US, compete for influence in the region, but also one in which the Central Asian states themselves are active players. In order to explain the geostrategic importance of Central Asia, it is necessary to mention the interests of other countries in the region. The relationship with Russia, the successor state to the USSR, is of vital importance. During the Soviet era, the USSR held the CARs as a liability and gave them independence without much resistance. It soon regretted its decision after it realized that the CARs are important countries because other countries are trying to influence the CARs. Hence, Russia started actively pursuing its interests in the region. The most important interest is to maintain its traditional regional hegemony. This essay critically examines the abovementioned fact in the context of Central Asian Republics' relations with its neighbors and the US.
\end{abstract}

ARTICLE INFORMATION

Received: 25 November 2016 Revised: 25 December 2016 Accepted: 25 December 2016

DOI:

http://dx.doi.org//10.31580/jmi.v12i1.64

\section{Introduction}

Central Asian States consist of Kazakhstan, Uzbekistan, Turkmenistan, Tajikistan and Kyrgyzstan spreading over an area of four million square kilometers. These states were formed as a result of the breakup of the USSR in 1991. The Classical Great Game of the $19^{\text {th }}$ century in the region was a contest between the Russian and British empires over Afghanistan due to its geostrategic importance. The "New Great Game", being played out in Central Asia, is one in which powers on the borders of the Central Asian states, as well as the US, compete for influence in the region, but also one in which the Central Asian states themselves are active players. The "New Great Game", in essence, is a race for the vast mineral resources of the region. The region's geostrategic importance is also due to many other reasons. The Central Asian Republics are strategically located at the meeting point of Asia and Europe. They also have borders with regional big powers i.e. Russia and China. Lastly, the border of three CARs with Afghanistan has increased its value as a result of the global "War on Terror". Due to these geostrategic and economic reasons, Central Asia has become a 'melting pot' in which the interests and strategies of powerful states interact, collide and converge. This essay critically examines the above mentioned fact in the context of Central Asian Republics' relations with its neighbors and the US.

In order to explain the geostrategic importance of Central Asia, it is necessary to mention the interests of other countries in the region. The relationship with Russia, the successor state to the USSR, is of vital importance. During the Soviet era, the USSR held the CARs as a liability and gave them independence without much resistance. It soon regretted its decision after it realized that the CARs are important countries because other countries are trying to influence the CARs.
Hence, Russia started actively pursuing its interests in the region. The most important interest is to maintain its traditional regional hegemony. The Tashkent Treaty, known as Collective Security Treaty Organization (CSTO), was signed in 1992 to achieve this goal. The Russia-led CSTO is responsible for the collective defense of Russia, Belarus, Armenia and the four Central Asian states except Turkmenistan (Government of Russia). This gives leverage to Russia over security matters in the region.

Secondly, Russia intends to protect and expand its own economic interests in the region. The Eurasian Economic Community (EEC) was formed in 2010 to improve regional economic integration. The member states of EEC are Russia, Belarus, Kazakhstan, Kyrgyzstan and Tajikistan. In 2007, three members (Russia, Belarus and Kazakhstan) of the EEC signed a deal to establish a customs union. Russia intends to turn the EEC into Eurasian Economic Union (EEU) after the remaining EEC members join the customs union (Beshimov, 2014)). Similarly, the Central Asia-Center gas pipeline system, a $5000 \mathrm{~km}$ long gas pipeline (it runs through Turkmenistan, Uzbekistan and Kazakhstan), allows both Uzbek and Turkmen gas to be supplied to Russia, which then resells it at a profit to Europe (Government of Russia). Thirdly, Russia seeks to stop the spread of Islamic fundamentalism in the region which can help the separatist movement in Chechnya. Lastly, Russia aims to protect the 8-10 million ethnic Russians living in the CARs.

China also has vital interests in the region. It primarily aims to develop Central Asia as an alternative source of oil and gas. The 3,666 km long 'China-Central Asia Gas Pipeline' transports around $21.3 \mathrm{bcm}$ of gas annually from the gas-rich Turkmenistan (through Uzbekistan and Kazakhstan) to China. The pipeline is destined to supply more than 40 percent of China's gas by 2020 (PRC). Similarly, Kazakhstan, which is the top oil producer in the region, 
exports oil to China. The 1,384 miles Kazakhstan-China oil pipeline runs from Kazakhstan to Xinjiang in China (Contessi, 2014). Chinese pipelines help Kazakhstan and Turkmenistan to redirect their resources away from Russia, declining their dependency on Moscow. Moreover, Russia and Central Asia overall trade turnover reached \$27.3bn in 2011, when China's trade with Central Asia topped \$46bn in 2012.

Secondly, Beijing aims to incorporate the Central Asian States in its vision of the "New Silk Road", which aims to connect China to Europe. China and Turkmenistan signed the China-Turkmenistan Friendly Cooperation Agreement, giving priority to Beijing's Silk Road Economic Belt (Tiezzi, 2014). Thirdly, China aims to establish a stable security environment in the region so that instability does not flow into China. In Xinjiang, Muslims of Turkish origin, called Uighurs, want an independent 'State of Turkestan'. China aims to stop the spread of Islamic fundamentalism in the region which can help the separatist movement in Xinjiang. Lastly, China aims to counter separatism, terrorism and extremism through bilateral and multilateral efforts. In this context, The Shanghai Cooperation Organization (SCO), formerly known as The Shanghai Five, was formed in 2001. It consists of Russia, China, Kazakhstan, Tajikistan, Uzbekistan and Kyrgyzstan. It mainly focuses on security issues but also touches upon economic cooperation.

The United States' major objective in Central Asia is to maximize cooperation with states of the region for security cooperation. It has focused on securing airbases for US and NATO forces in Central Asia to help in the Afghan War. The United States had two airbases in the region, the Karshi-Khanabad Airbase in Uzbekistan and the Manas Airbase in Kyrgyzstan. However, both were closed, the former in 2005 and the latter in 2014, due to pressures from SCO. Moreover, the United States makes sure the availability of transit of troops and supplies through the "Northern Distribution Network". The most common route in the NDN complex starts from Latvia near the Baltic Sea and passes through Russia, Kazakhstan and Uzbekistan to reach Afghanistan.

The second objective of Washington is to increase the development and diversification of the region's energy resources and supply routes. The purpose is to make sure the availability of energy resources to its allies, Japan and European countries. This is evident from the United States' financial support to the the $1,768 \mathrm{~km}$ long Baku-TbilisiCeyhan pipeline, linking the Caspian Sea to Turkey's Ceyhan port in the Mediterranean Sea. The third major objective of the United States in the region is the sustenance of non-proliferation. The IAEA reported that Kazakhstan had around 10 tons of HEU (Highly Enriched Uranium) with average enrichment of around $20 \%$ in the form of spent fuel from the BN-350 reactor in Kazakhstan, which was shut down under US pressure in 1999. The last US objective in the region is to combat the trafficking of narcotics and people in Central Asia.

Turkey, due to its historical (as it was part of the Ottoman Empire), cultural and religious (Islam) connections with Central Asia, is also active in the region. Cultural connections are due to the same Turkic origin (Turkish people belong to Central Asia) and language of people of both areas. All the languages spoken in Central Asia belong to the "Turkic language group". In this regard, The Cooperation Council of Turkic-Speaking States (CCTS), holds the "Summit of Turkic Speaking Countries" annually in Turkey in order to increase solidarity between the Turkic Speaking Countries. Secondly, Turkey's ambition in the region is to promote itself as a development model. Turkey, under the Justice and Development Party (AKP), has rapidly developed economically and politically. Over the period 2002-201, Turkey has recorded an average GDP growth rate of $6 \%$.

Ankara's third goal in the region is to undertake investment in the oil and gas sectors of the region. This is evident from the huge FDI of $\$ 4.7$ billion from Turkey in the CARs and the contracts given to the nearly 2000 Turkish companies operating in Central Asia which are valued at $\$ 50$ billion. It also imports $75 \%$ of its oil and gas from outside including Central Asia. Moreover, Turkey offers secure transit of oil and gas supplies from the CARs to Western markets via Turkey.
In this connection, the Turkmenistan-Iran-Turkey (TIT) pipeline is under discussion which will transport Turkmen and Iranian gas to Europe via Turkey.

Iran, which has linguistic affinities with the Tajik people (who speak Persian), also want a part of the pie. Its primary objective in the region is to promote trade, especially in the energy sector. It already has established road, rail and air links with the Central Asian States. It was the founding member of the ECO and is an observer member of the SCO. In spite of these factors, Iran has been unsuccessful in developing strong ties with the CARs. This is due to heavy sanctions on Iran and pressures from the US on the CARs to cut ties with Iran. Secondly, the CARs are apprehensive of the extremist tendencies of Iran which, according to the CARs, may bring this mindset to Central Asia. Finally, the territorial disputes in the Caspian Sea have also hampered economic cooperation. The Caspian Sea has one of the largest reservoirs of oil and gas in the world with 48 billion barrels of oil and 292 trillion cubic feet of natural gas reserves (15). Iran opposes the division of the sea as it stands to lose if International Law is applied in dividing the Caspian Sea among the countries bordering the sea.

Pakistan, founding member of the ECO and an observer member the SCO also wants to promote economic, political and commercial ties with the CARs. Its principal interest in the region is to provide it access to the warm waters of the Indian Ocean via Gwadar, which Pakistan claims to be the shortest route. Pakistan is also interested in the proposed $1,735 \mathrm{~km}$ Turkmenistan-Afghanistan-Pakistan-India (TAPI) gas pipeline funded ( $\$ 7.6$ billion) by the ADB. Although Pakistan is willing to increase economic and political cooperation, the greatest obstacle is the instability in Afghanistan. Lastly, the lack of road infrastructure hampers the Gwadar project.

India has also initiated an ambitious strategy to establish a firm foothold in the CARs in the political, economic, commercial, culture and security arenas. Competition with China and Pakistan in the region is the greatest motivation for India. India, which is swiftly rising militarily and economically, needs energy which the CARs have in abundance. Moreover, due to the CARs borders with Afghanistan (where India has invested heavily), India is wary of the spread of what it perceives as Pakistan backed radical Islam. Thirdly, India wants to increase bilateral and multilateral ties (it has observer status in the SCO) in the military sphere. Last of all, it wants to build up on its "soft-power" to enhance cooperation in cultural and educational fields. India wants to provide education to Central Asia at a much lower price but of the same quality as the west. Similarly, it offered help in the medical, IT and technology fields.

\section{Conclusion}

In conclusion, due to geostrategic and economic reasons, the interests of major global and regional powers converge in Central Asia. Kazakh oil, Turkmen gas, Tajik hydroelectricity and the overall geostrategic position of Central Asia makes it an interesting ground for the "New Great Game" but the fascinating fact is that the CARs are themselves involved in the game. The Central Asian states are able to increasingly promote their own game plan by diversification of their supply chains and pipelines which are meant to end its dependency on Russia. The rising economic relationship with China can be a win-win situation for both the countries, in which china provides funds and Central Asia fulfills China's massive energy thirst. But if the Central Asian leadership is not cautious enough, they will end up escaping the grip of one great power, only to be replaced by the dominance of another. Hence, in the "New Great Game", the Central Asian States themselves have to play a great role, in order to benefit from its vast resources as well as maintain its national sovereignty.

\section{References}

"Collective Security Treaty Organization (CSTO)." Globalsecurity.org. N.p., n.d. Web. 
Beshimov, Baktybek. "The Struggle for Central Asia: Russia vs China." Opinion. AlJazeera, n.d. Web. 27 Oct. 2014.

"Евразийское экономическое сообщество." ЕврАзЭС. Government of China, n.d. Web. 27 Oct. 2014.

Tiezzi, Shannon. "China's 'New Silk Road' Vision Revealed." The Diplomat. The Diplomat, n.d. Web. 27 Oct. 2014.
Contessi, Nicola. "Is Turkmenistan the Next Central Asian Tiger?" The Diplomat. The Diplomat, n.d. Web. 27 Oct. 2014.

"Central Asia - Center." Central Asia - Center. Government of Russia, n.d. Web. 27 Oct. 2014. 